\title{
Peran Perguruan Tinggi dalam Pengelolaan Perkebunan Kopi di Wawowae-Ngada, Nusa Tenggara Timur
}

\author{
Oleh \\ Folkes E. Laumal $^{1}$, Jhon A. Wabang ${ }^{2}$, Raden Budi Suharto ${ }^{3}$, Nina Lapinangga ${ }^{4}$, Josina I. B. Hutubessy ${ }^{5}$ \\ 1,2,3 Politeknik Negeri Kupang, Kupang - Indonesia \\ ${ }^{4}$ Politeknik Pertanian Negeri Kupang, Kupang - Indonesia \\ ${ }^{5}$ Universitas Flores, Ende - Indonesia \\ Email: folkeslaumal76@gmail.com,jhonarwabang@gmail.com,budi_suharto@yahoo.com, \\ ninalapinangga@yahoo.co.id, irenehutubessy91@yahoo.co.id
}

\begin{abstract}
Abstrak
Wawowae adalah satu desa di Kecamatan Bajawa berjarak $\pm 350 \mathrm{~km}$ dari ibu kota propinsi dengan Sumber daya potensial yaitu perkebunan Kopi. $50 \%$ dari \pm 978 wilayah Desa Wawowae adalah perkebunan kopi, sedangkan sisanya merupakan permukiman rakyat dan Hutan Cagar Alam. Pengolahan Kopi Gelondongan menjadi kopi HS secara konvensional melalui 3 tahapan, yaitu pengupasan, fermentasi/pencucian dan penjemuran. Permasalahan dalam pengelolaan kopi wawowae yaitu pembiaran pertumbuhan, minimnya prasarana pengolahan dan lamanya proses pengeringan memberikan dampak penurunan kualitas kopi HS ketika dijual. Dengan metode penyuluhan dan mekanisasi memungkinkan terjadinya peningkatan produksi kopi, peningkatan sumber daya manusia bahkan kesejahteraan masyarakat dan Desa Wawowae dapat menjadi icon pengelolaan kopi di Nusa Tenggara Timur. Penanganan pengelolaan kopi Wawowae melibatkan peran perguruan tinggi yang berada di NTT dengan keterlibatan pemerintah daerah untuk bersama memajukan masyarakat NTT (Wawowae khususnya). Masing-masing perguruan tinggi dengan ketersediaan sumberdaya dapat bersinergi secara optimal memberikan pemberdayaan kepada wilayah-wilayah berpotensi khususnya pengelolaan Kopi di Wawowae, sehingga mampu memberikan pengaruh yang signifikan kepada pengembangan wilayah dan masyarakat serta kesejahteraan.
\end{abstract}

Kata Kunci: Wawowae, kopi, NTT, pemberdayaan

\section{Pendahuluan}

Wawowae adalah satu dari 13 desa di Kecamatan Bajawa, Kota Bajawa, Kabupaten Ngada, Nusa Tenggara Timur yang terletak pada ketinggian $1000-1500 \mathrm{~m}$ di atas permukaan laut. Wilayah desa ini memiliki 4 dusun, yaitu Ekoheto, Wolowio, Boloma dan Borewu. Desa ini berjarak $\pm 350 \mathrm{~km}$ dari ibu kota propinsi (Kota Kupang) dan dapat ditempuh dengan penerbangan \pm 50 menit ke Bandara So'a Ngada, dilanjutkan dengan perjalanan darat \pm 15 menit melewati Kota Bajawa [1]. Seiring perkembangan infrastruktur di Kabupaten Ngada, struktur jalan dari Bandara So'a ke Wawowae sudah hotmix, sehingga perjalanan menjadi lebih cepat dan nyaman baik menggunakan kendaraan roda 2 maupun roda 4 . Pengelolaan kopi di Wawowae dilakukan secara berkelompok dengan hasil setiap kali panen dapat menghasilkan \pm 1500 ton untuk 10 kelompok tani. Kopi yang dipanen setiap tahun, diolah menjadi kopi HS (kopi biji dengan kulit ari masih menempel) dan dijual ke wilayah lain. Sumber daya yang sangat potensial di Wawowae yaitu perkebunan Kopi. Dari \pm 978 ha luas desa, lebih dari $50 \%$ wilayah adalah perkebunan kopi, sedangkan sisanya merupakan permukiman rakyat dan Hutan Cagar Alam. Struktur tanah pegunungan yang subur, memberikan perkembangan yang baik bagi tanaman kopi sehingga biarpun tidak dirawat intensif, namun tanaman kopi di wilayah ini tetap berkembang secara alami. Jumlah penduduk Wawowae hingga tahun $2016 \pm 490$ KK (1226 jiwa), dimana $99 \%$ masyarakat berprofesi sebagai 
petani kopi, hanya $1 \%$ berprofesi sebagai Guru, TNI dan wiraswasta [2].

Pengelolaan kopi di Wawowae dilakukan secara berkelompok. Terdapat \pm 10 kelompok tani terdaftar di Kantor Desa Wawowae, yaitu Lideriwu1, Lideriwu2, Bomadha, Borewu, Mawar, Ledo Leza, Zoodhoo, Ratu Berdukacita dan Cinta Alam dengan jumlah anggota yang beragam antara 10 hingga 30 orang/kelompok. Setiap anggota kelompok rata-rata mengelola 1 ha kebun kopi, sehingga dalam sekali panen, Kopi Gelondongan yang dapat dihasilkan \pm 5 ton/petani atau \pm 150 ton per kelompok. Jika ditotal, untuk 3 kelompok dapat menghasilkan rata-rata 450 ton atau \pm 1500 ton untuk 10 kelompok. Kopi yang dipanen setiap tahun, selalu diolah menjadi kopi HS (kopi biji dengan kulit ari masih menempel) dan dijual ke wilayah lain. Hanya sedikit saja yang disimpan untuk konsumsi sehari-hari [3].

Sampai saat ini, pengolahan Kopi Gelondongan menjadi kopi HS oleh kelompok-kelompok petani di Desa Wawowae masih dilakukan secara konvensional melalui 3 tahapan, yaitu pengupasan, fermentasi/pencucian dan penjemuran [4][5]. Tahapan Pengupasan dilakukan dengan menyewa mesin dari perusahaan/pengusaha di luar desa dengan harga diantara Rp. 15000 s/d Rp. 25000 per orang sekali pakai. Terdapat satu kelompok tani yang memiliki mesin Pulper sederhana namun tidak mampu mengola semua hasil dari kelompok karena kapasitas Pulper hanya maksimum $2 \mathrm{~kg}$. Tahapan Pencucian/Fermentasi tidak langsung dilakukan, karena sebagian kopi dari Pulper (Kopi HS basah) masih tercampur dengan kulit, sehingga perlu tambahan waktu dan tenaga lagi untuk memisahkan/membersihkan kulit yang masih menempel secara manual. Pencucian dilakukan secara konvensional pada wadah kawat berukuran $\pm 80 \times 200 \mathrm{~cm}$ lalu disiram dengan air bersih sambil diaduk dengan tangan hingga kopi benar-benar bersih. Kopi kemudian disebar merata pada wadah yang sama dan dijemur sekitar 5-6 hari. Wadah penjemuran ditempatkan langsung di atas tanah (tidak tersusun seperti rak), sehingga sering mendapat gangguan dari hewan yang berkeliaran.

Terdapat beberapa persoalan dalam pengelolaan Kopi di Desa Wawowae. Dalam hal pengelolaan tanaman kopi, pembiaran pertumbuhan dan perkembangan secara alami dapat menurunkan kualitas dan kuantitas hasil panen apabila tidak menerapkan mekanisme perawatan dan budidaya yang teratur dan berkelanjutan, sesuai kondisi iklim setempat. Ketika panen, pengolahan konvensional Kopi Gelondongan membutuhkan waktu yang lama sehingga kesegaran kopi dapat menurun dan memberi pengaruh pada kualitas Kopi HS yang dihasilkan. Proses fermentasi konvensional juga menyebabkan kopi mengering lebih lama, apalagi petani hanya menaksir tingkat kekeringan biji kopi karena tidak memiliki alat pengukur kadar air. Kurangnya pengetahuaan tentang manajemen penjualan dan strategi bisnis juga menjadi masalah karena kelompok petani hanya menjual sendiri-sendiri Kopi HS yang telah dihasilkan. Distribusi penjualan Kopi HS dari Wawowae sudah tersebar ke beberapa daerah di luar Kota Bajawa. Daratan Flores, Kota Kupang, Denpasar, Surabaya, Semarang, Bandung dan Jakarta. Bahkan sudah ada peneliti dari Malaysia yang membawa sampel Kopi Wawowae untuk diteliti di Malaysia.

\section{Metode}

Beberapa metode pengelolaan dapat diimplementasikan pada pengelolaan kopi di Desa Wawowae, Pertama, melalui penerapan teknologi perawatan hama dan penyakit tanaman, tingkat kesuburan, pembudidayaan anakan, penanaman kembali dan perawatan pertumbuhan anakan. Metode kedua yaitu evaluasi dan kontrol penyebaran hama pada tanaman dan pertumbuhan tanaman kopi. Metode ketiga yaitu penanganan hasil panen, kelompok-kelompok petani kopi di Wawowae 
memerlukan sentuhan teknologi mesin yang lebih besar agar tidak ada lagi penyewaan dalam mengolah kopi gelondongan, waktu proses menjadi lebih cepat dan kualitas kopi HS yang dihasilkan juga menjadi lebih baik. Teknologi mesin yang dapat diterapkan diantaranya mesin pulper, mesin fermentasi dan pengukur kadar air. Metode keempat yaitu peningkatan sumber daya manusia melalui pelatihan dan pendampingan tata kelola tanaman, pemanfaatan mesin-mesin produksi, manajemen bisnis dan akuntansi yang berbasis ICT. Penerapan meotde ini kemungkinan terjadinya peningkatan produksi kopi, peningkatan sumber daya manusia bahkan kesejahteraan masyarakat menjadi lebih besar dan Desa Wawowae dapat menjadi icon pengelolaan kopi di Nusa Tenggara Timur.

\section{Pembahasan}

Untuk mengatasi persoalan dengan gambaran tahapan di atas, maka kita tidak bisa berharap hanya kepada pemerintah daerah saja, namun keterlibatan masyarakat perguruan tinggi menjadi sangat penting dalam menerapkan Ilmu Pengetahuan dan Teknologi (IPTEK) yang dimilikinya [6]. NTT punya beberapa perguruan tinggi negeri dan swasta. Beberapa diantaranya yaitu UNDANA, Universitas Muhamadiyah, Universitas Kristen Artha Wacana, Universitas Katolik Widya Mandira, Politeknik Negeri Kupang, Politeknik Pertanian Negeri Kupang, Universitas Tribuana Kalabahi, Universitas Flores dan beberapa perguruan tinggi swasta dan sekolah tinggi lainnya. Sumber daya dan teknologi yang dimilik oleh perguruan tinggi sangat memungkinkan diterapkan untuk pengembangan potensi sumber daya di Desa Wawowae, baik untuk bidang pertanian, perkebunan, hama penyakit, teknologi permesinan dan elektronika, manajemen, bisnis dan akuntansi yang berbasis internet/ICT. Ketersediaan sumber daya di beberapa perguruan tinggi di Nusa Tenggara Timur yang berhubungan erat dengan sumberdaya perkebunan kopi di Wawowae (dan NTT pada umumnya), diberikan pada Tabel 1 .

Tabel 1. Penggolongan Ketersediaan Sumber Daya di beberapa Perguruan Tinggi di NTT

\begin{tabular}{|c|c|c|c|}
\hline No & $\begin{array}{c}\text { Perguruan } \\
\text { Tinggi }\end{array}$ & Lokasi & $\begin{array}{l}\text { Ketersediaan } \\
\text { Sumber Daya }\end{array}$ \\
\hline 1. & $\begin{array}{l}\text { Universitas } \\
\text { Nusa Cendana }\end{array}$ & Kupang & $\begin{array}{l}\text { Pertanian, } \\
\text { Peternakan }\end{array}$ \\
\hline 2. & \begin{tabular}{l}
\multicolumn{2}{l}{ Universitas } \\
Kristen Artha \\
Wacana \\
Kupang
\end{tabular} & Kupang & $\begin{array}{l}\text { Pertanian, } \\
\text { Peternakan }\end{array}$ \\
\hline 3. & $\begin{array}{l}\text { Universitas } \\
\text { Katolik Widya } \\
\text { Mandira } \\
\text { Kupang }\end{array}$ & Kupang & Ekonomi \\
\hline 4. & $\begin{array}{l}\text { Universitas } \\
\text { Muhammadiyah } \\
\text { Kupang }\end{array}$ & Kupang & Ekonomi \\
\hline 5. & $\begin{array}{l}\text { Politeknik } \\
\text { Negeri Kupang }\end{array}$ & Kupang & $\begin{array}{l}\text { Mesin, } \\
\text { Elektro }\end{array}$ \\
\hline 6. & $\begin{array}{l}\text { Politeknik } \\
\text { Pertanian } \\
\text { Negeri Kupang }\end{array}$ & Kupang & $\begin{array}{l}\text { Pertanian, } \\
\text { Peternakan }\end{array}$ \\
\hline 7. & $\begin{array}{l}\text { Universitas } \\
\text { Flores }\end{array}$ & Ende & Pertanian \\
\hline 8. & $\begin{array}{l}\text { Universitas } \\
\text { Timor }\end{array}$ & TTU & Pertanian \\
\hline 9. & $\begin{array}{l}\text { Universitas } \\
\text { Tribuana } \\
\text { Kalabahi }\end{array}$ & Alor & Pertanian \\
\hline
\end{tabular}

Tabel 1 menggambarkan bahwa dari sejumlah perguruan tinggi yang berada di NTT, 9 diantaranya memang memiliki ketersediaan sumberdaya yang berhubungan erat dengan potensi wilayah Wawowae dan NTT secara keseluruhan. Sinergitas dan optimalisasi pemberdayaan kepada wilayah-wilayah berpotensi tentunya akan memberikan pengaruh yang signifikan kepada pengembangan wilayah dan masyarakat serta kesejahteraan [7].

Pemerintah daerah juga perlu membuka diri dan bekerjasama dengan perguruan tinggi melalui penyediaan kebijakan dan anggaran yang memberi peluang bagi peningkatan pengelolaan 
sumber daya di NTT khususnya di Desa Wawowae, baik pemerintah kabupaten, maupun pemerintah propinsi Nusa Tenggara Timur.

\section{Kesimpulan}

Dengan jumlah $99 \%$ masyarakat petani kopi dan lebih dari $50 \%$ wilayah adalah kebun kopi, menjadi sangat strategis untuk dikembangkan, jika pengelolaan ini optimalkan dengan sentuhan hasil-hasil penelitian PT dalam bidang teknologi, bimbingan dan penyuluhan. Optimalisasi juga akan membuat potensi desa menjadi lebih cepat dikenal masyarakat nasional/internasional, berkembang dan meningkatkan kesejahteraan yang lebih baik bagi masyarakat di Desa Wawowae. Walaupun manajemen pengelolaan masih konvensional, namun masyarakat Desa Wawowae sudah berani mengolah menghasilkan kopi HS yang cukup banyak ( \pm 1500 ton) dan didistribusikan sampai ke kota lain. Jika dengan proses manual saja, kualitas kopi HS yang dihasilkan sudah dapat menarik para distributor bahkan sedang diincar oleh peneliti dari Malaysia, maka dengan mengoptimalkan sentuhan hasil-hasil penelitian PT, pengolahan kopi akan menjadi lebih maksimal dari segi kualitas dan kuantitasnya. Bahkan bisa dijadikan pusat kajian bagi peneliti kopi di negara lain. Keterlibatan perguruan tinggi dan keterbukaan pemerintah daerah untuk bekerjasama dipastikan dapat membawa dampak positif bagi kemajuan Desa Wawowae sehingga dapat dikenal sebagai desa sentra kopi secara regional, nasional/internasional.

\section{Daftar Pustaka}

[1] wikipedia, "Wawowae, Bajawa, Ngada," 2016. .

[2] Badan Pusat Statistik Indonesia, Kepala Badan Pusat Statistik. 2010, p. 681.

[3] F. E. Laumal, "Hasil Survei Data Desa Wawowae," Ngada, 2017.

[4] P. D. A. N. Mutu, "Pengembangan Tanaman Kelapa," pp. 1-31, 2013.

[5] J. R. Saragih, "Produksi Kopi Arabika Spesialti Sumatera Utara : Analisis Sosial Ekonomi, Ekologi, dan Kebijakan Pemerintah Daerah," pp. 1-11, 2016.

[6] Pemerintah Daerah Provinsi Nusa Tenggara Timur, "Provinsi Nusa Tenggara Timur 2015 ANALISIS PEMBANGUNAN WILAYAH PROVINSI NUSA TENGGARA TIMUR," 2015.

[7] P. An and S. Rdaya, "Peranan perguruan tinggi dalam pembangunan sumber daya manusia," no. SePtember, 1994. 